\title{
Preparation and immunogenicity of tag-free recombinant human eppin
}

\author{
Jie Zhang ${ }^{1, *}$, Xin-Liang Ding ${ }^{2, *}$, Zeng-Hui Bian ${ }^{3}$, Yan-Kai Xia ${ }^{4}$, Shou-Lin Wang ${ }^{4}$, Ling Song ${ }^{4}$ and Xin-Ru Wang $^{4}$ \\ Human epididymal protease inhibitor (eppin) may be effective as a male contraceptive vaccine. In a number of studies, eppin with an \\ engineered $\mathrm{His}_{6}$-tag has been produced using prokaryotic expression systems. For production of pharmaceutical-grade proteins for \\ human use, however, the $\mathrm{His}_{6}$-tag must be removed. This study describes a method for producing recombinant human eppin without a \\ $\mathrm{His}_{6}$-tag. We constructed plasmid pET28a (+)-His ${ }_{6}$-tobacco etch virus (TEV)-eppin for expression in Escherichia coli. After \\ purification and refolding, the fusion protein $\mathrm{His}_{6}$-TEV-eppin was digested with TEV protease to remove the $\mathrm{His}_{6}$-tag and was further \\ purified by NTA-Ni ${ }^{2+}$ affinity chromatography. Using this procedure, $2 \mathrm{mg}$ of eppin without a $\mathrm{His}_{6}$-tag was isolated from $1 \mathrm{I}$ of culture \\ with a purity of $>95 \%$. The immunogenicity of the eppin was characterized using male Balb/c mice.
}

Asian Journal of Andrology (2011) 13, 889-894; doi:10.1038/aja.2011.89; published online 5 September 2011

Keywords: Eppin; immunogenicity; male contraception; recombinant protein preparation; tag-free

\section{INTRODUCTION}

Epididymal protease inhibitor (eppin; SPINLW1) is a serine protease inhibitor-like protein that has been proposed as a target for a novel male contraceptive method. ${ }^{1}$ Eppin was discovered in 2001 as a cysteine-rich protein that contains both Kunitz-type and WAP-type four disulfide core protease inhibitor consensus sequences. ${ }^{2}$ Subsequent studies showed that the protein is specifically expressed in the testis and epididymis in primates and rodents. ${ }^{2,3}$ In both sets of species, two isoforms of eppin are present: one isoform is secreted, and the other lacks a signal sequence. ${ }^{2}$ Functional studies of eppin have focused on the form that lacks a signal sequence. ${ }^{4-7}$ The importance of eppin in male reproduction was confirmed by the demonstration of a reversible contraceptive effect in male monkeys immunized with recombinant human eppin and by the upregulation of EPPIN gene expression in non-obstructive azoospermia patients. ${ }^{1,8}$ In further studies, we found that variants of the EPPIN gene affect the risk of idiopathic male infertility in the Han-Chinese population. ${ }^{9,10}$ However, the molecular mechanism of eppin action is not presently understood.

The expression and purification of recombinant protein often represents a first step in the study of a new protein. ${ }^{11}$ In previous studies, recombinant human eppin with an $\mathrm{N}$-terminal poly-histidine $\operatorname{tag}\left(\mathrm{His}_{6}\right.$-tag) was used to investigate the protein's function. ${ }^{1,6,7,12,13}$ However, tags, whether large or small, have the potential to interfere with the biological activity of a protein, ${ }^{14,15}$ and the $\mathrm{His}_{6}$-tag cannot be used for the production of pharmaceutical-grade proteins. ${ }^{16}$ Several strategies have been used to remove fusion tags from proteins after purification. ${ }^{14,17}$ Cleavage by a specific endoprotease at a specifically recognized sequence inserted between the tag and the target protein is a feasible way to remove the fusion tag. ${ }^{18}$ The endoproteases most commonly used for this purpose are factor Xa, enterokinase (enteropeptidase, EK) and thrombin. ${ }^{15}$ These endoproteases do not exhibit stringent sequence specificity and often cleave at non-target sites. ${ }^{19}$ Recently, viral proteases, including the tobacco etch virus (TEV), ${ }^{18}$ have been used as endoproteases to remove fusion tags; such proteases offer the advantage of a high stringency of sequence recognition.

In this study, we expressed eppin as a recombinant protein with an $\mathrm{N}$-terminal $\mathrm{His}_{6}$-tag and an intervening TEV endoprotease recognition site to facilitate tag removal and removed the $\mathrm{His}_{6}$-tag from the recombinant protein using TEV endoprotease. We immunized $\mathrm{Balb} / \mathrm{c}$ mice with the purified eppin and detected high-titer antibodies to eppin in the serum. The production of tag-free eppin will facilitate the study of its structure-function relationship and may contribute to the development of potential clinical applications of this protein.

\section{MATERIALS AND METHODS}

\section{Materials}

Human epididymal tissues were generously provided by patients at the Affiliated Hospitals of Nanjing Medical University (Nanjing, China), who gave informed consent for the use of tissues obtained by surgical resection. The Escherichia coli TOP10 competent cells and BL21 Star (DE3) competent cells were purchased from Invitrogen Life Technologies (Carlsbad, CA, USA). The expression vector pET28a $(+)$ and TEV endoprotease were generous gifts from Dr Zi-Chun Hua, The State Key Laboratory of Pharmaceutical Biotechnology and Department of Biochemistry, College of Life Science, Nanjing

${ }^{1}$ School of Radiation Medicine and Public Health, Medical College of Soochow University, Suzhou 215123, China; ${ }^{2}$ Department of Public Health, Wuxi Center for Disease Prevention and Control, Wuxi 214023, China; ${ }^{3}$ Municipal Center for Disease Control and Prevention, Nanjing 210003, China and ${ }^{4}$ Key Laboratory of Reproductive Medicine, Institute of Toxicology, Nanjing Medical University, Nanjing 201129, China

* These authors contributed equally to this work.

Correspondence: Dr XR Wang (xrwang@njmu.edu.cn)

Received: 8 November 2010; Revised: 7 January 2011; Accepted: 21 April 2011; Published online: 5 September 2011 
University, China. The gel extraction kit was from Qiagen (Valencia, Canada); plasmid extraction kits were purchased from Tiangen Biotech Co., Ltd (Beijing, China). Restriction enzymes, Taq DNA polymerase, dNTPs, M-MuLV reverse transcriptase, ribonuclease inhibitor and T4 DNA ligase were obtained from MBI Fermentas (Burlington, Canada). Primers were synthesized by Invitrogen (Shanghai, China). All other reagents were of research grade and were obtained from commercial sources.

\section{Cloning of the EPPIN gene and construction of its expression plasmid}

Total RNA was extracted from human epididymal tissue using TRIzol reagent according to the manufacturer's protocol. EPPIN cDNA (nucleotides 86-434) lacking part of the $N$-terminal secretory sequence was generated by reverse transcriptase polymerase chain reaction using total epididymal RNA as a template. Gene-specific primers were used to amplify EPPIN cDNA. The forward primer was 5'-CGGTCATATGGAAAACCTGTATTTTCAGGGCGTCCAGGGACCTGGTCTGA-3'; this primer contains four protective base pairs (CGGT), an NdeI site (CATATG) and a nucleotide sequence encoding the TEV endoprotease (GAAAACCTGTATTTTCAGGGC). The reverse primer was 5'-GTTCGAGCTCTCAGGGAAAGCGTTTATTCTTGCAG-3', which contains four protective base pairs (GTTC) and a SacI site (GAGCTC). The amplified EPPIN cDNA fragment was double-digested by NdeI/SacI and cloned into the pET28a (+) vector, which was digested in the same manner, to produce the pET28a $(+)$-eppin plasmid. The plasmid was transformed into E. coli TOP10 competent cells, and positive clones were validated by DNA sequencing.

\section{Time course expression study and protein expression analysis} The pET28a (+)-eppin plasmid was transformed into E. coli BL21 Star (DE3) competent cells for expression of the recombinant protein $\mathrm{His}_{6}$-TEV-eppin. Single clones were inoculated into $5 \mathrm{ml}$ of Luria-Bertani medium with $100 \mu \mathrm{g} \mathrm{ml}^{-1}$ of kanamycin and incubated at $37{ }^{\circ} \mathrm{C}$ with centrifugation at $280 \mathrm{~g}$ overnight. The next day, $200 \mu \mathrm{l}$ of the overnight culture was used to inoculate $20 \mathrm{ml}$ fresh Luria-Bertani, and the fresh culture was incubated at $37^{\circ} \mathrm{C}$ until its optical density at $600 \mathrm{~nm}$ (o.d.600) was about 0.6 (about $2 \mathrm{~h}$ ). Protein expression was induced by the addition of IPTG to a final concentration of $1 \mathrm{mmol}^{-1}$ and cultured at $37{ }^{\circ} \mathrm{C}$ at $280 \mathrm{~g}$ or various time durations. Two milliliters of bacterial culture were removed at time points $0,1,2,3,4$ and $5 \mathrm{~h}$ after induction. The cell pellets were collected from the samples by centrifugation at $12000 \mathrm{~g}$ or $10 \mathrm{~min}$ at $4{ }^{\circ} \mathrm{C}$, resuspended in $30 \mu \mathrm{l}$ of sodium dodecyl sulfate (SDS) sample loading buffer and analyzed by $15 \%$ SDSPAGE. The Coomassie-stained SDS-PAGE gel was scanned with a UVP white/ultraviolet trans-illuminator, and the protein bands were quantified using Grab-it 2.5 and Gelwork software.

To determine whether the expressed protein was soluble or insoluble, cells collected from $5 \mathrm{ml}$ of culture were resuspended in $0.5 \mathrm{ml}$ of distilled water and lysed by sonication. Insoluble proteins were collected by centrifugation and dissolved in SDS sample loading buffer, while the supernatant with the soluble proteins was mixed with an equal volume of $2 \times$ SDS sample loading buffer; both fractions were analyzed by SDS-PAGE and Coomassie staining.

\section{Large-scale protein expression and purification procedure}

For large-scale protein expression, $10 \mathrm{ml}$ of an overnight culture of pET28a (+)-eppin- transformed BL21 Star (DE3) was used to inoculate 11 of Luria-Bertani medium containing kanamycin at $37{ }^{\circ} \mathrm{C}$. Induction was initiated at mid-log phase (o.d. ${ }_{600} \approx 0.6$ ) by the addition of IPTG to a $1 \mathrm{mmol}^{-1}$ final concentration. The cells were harvested after $4 \mathrm{~h}$ by centrifugation and stored at $-70{ }^{\circ} \mathrm{C}$ until protein purification.

To purify the recombinant proteins, the cell pellet was resuspended and sonicated in lysis buffer $\left(50 \mathrm{mmol} \mathrm{l}^{-1}\right.$ Tris, $100 \mathrm{mmol}^{-1}$ $\mathrm{NaCl}, \mathrm{pH}$ 8.0). After centrifugation, insoluble inclusion bodies were resuspended in binding buffer $\left(50 \mathrm{mmol}^{-1}\right.$ sodium phosphate, $300 \mathrm{mmol} \mathrm{l}^{-1} \mathrm{NaCl}, 8 \mathrm{~mol} \mathrm{l^{-1 }}$ urea, $\mathrm{pH} 8.0$ ) with $10 \mathrm{mmol} \mathrm{l}^{-1}$ reduced glutathione (GSH) and $2 \mathrm{mmol}^{-1}$ glutathione-oxidized form (GSSG) and dissolved overnight at room temperature. The dissolved liquid was centrifuged and the supernatant loaded onto a NiNTA agarose column. The column was washed with binding buffer and subsequently with wash buffer $\left(50 \mathrm{mmol} \mathrm{l}^{-1}\right.$ sodium phosphate, $300 \mathrm{mmol}^{-1} \mathrm{NaCl}, 8 \mathrm{~mol} \mathrm{l}^{-1}$ urea, $\mathrm{pH} \mathrm{6.0)}$. The bound protein was eluted with elution buffer $\left(50 \mathrm{mmol} \mathrm{l}^{-1}\right.$ sodium phosphate, 300 mmol $\mathrm{l}^{-1} \mathrm{NaCl}, 8 \mathrm{~mol} \mathrm{l}^{-1}$ urea, $250 \mathrm{mmol} \mathrm{l}^{-1}$ imidazole, pH 8.0).

The separated crude bacterial lysates (total, soluble and insoluble fractions) and purified $\mathrm{His}_{6}$-TEV-eppin were analyzed by SDS-PAGE. The percentage of $\mathrm{His}_{6}$-TEV-eppin expression was determined to be total induced $\mathrm{His}_{6}$-TEV-eppin/total protein in crude bacterial lysates $\times 100 \%$.

Protein refolding by dilution and concentration by ultrafiltration The eluted fraction $(50 \mathrm{ml})$ was immediately diluted to $400 \mathrm{ml}$ in refolding buffer (50 mmol ${ }^{-1}$ Tris, $100 \mathrm{mmol} \mathrm{l}^{-1} \mathrm{NaCl}, 0.4 \mathrm{~mol} \mathrm{l}^{-1}$ $L$-arginine, $10 \mathrm{mmol} \mathrm{l}^{-1} \mathrm{GSH}, 2 \mathrm{mmol} \mathrm{l}^{-1}$ GSSG, pH 8.0); the refolding buffer was added slowly by a constant flow pump at a velocity of $0.1 \mathrm{ml} \mathrm{min}{ }^{-1}$. After refolding by dilution, ultrafiltration in a stirred ultrafiltration cell (Millipore, Billerica, MA, USA) was performed to remove urea and imidazole from the protein solution. During the ultrafiltration process, the volume of the protein solution was reduced to $40 \mathrm{ml}$. Additional fresh buffer $\left(50 \mathrm{mmol}^{-1}\right.$ $\mathrm{NaH}_{2} \mathrm{PO}_{4}, 100 \mathrm{mmol} \mathrm{l}^{-1} L$-arginine, $\mathrm{pH}$ 7.4) was then added to bring the volume to $400 \mathrm{ml}$. This ultrafiltration process was repeated eight times to completely remove urea and imidazole. The purified protein was stored at $-70{ }^{\circ} \mathrm{C}$.

\section{Time course of $\mathrm{His}_{6}$-TEV protease digestion}

To determine the optimal cleavage time, $0.5 \mathrm{mg}$ of purified recombinant protein was incubated with $0.01 \mathrm{mg}$ of $\mathrm{His}_{6}$-TEV protease (TEV/substrate ratio $=1: 50$ ) in $1 \mathrm{mmol} \mathrm{l}^{-1}$ DTT, $50 \mathrm{mmol} \mathrm{l}^{-1}$ Tris, $\mathrm{pH} 8.0$, at $20^{\circ} \mathrm{C}$ for $0,2.5,5$ and $7 \mathrm{~h}$, and the products were analyzed by $15 \%$ SDS-PAGE and Coomassie staining.

\section{Cleavage of $\mathrm{His}_{6}$-tag and purification of eppin}

Purified, renatured and ultrafiltered $\mathrm{His}_{6}-\mathrm{TEV}$-eppin was digested using $\mathrm{His}_{6}$-TEV protease as described above. In brief, $12 \mathrm{mg}$ of substrate was incubated at $20{ }^{\circ} \mathrm{C}$ for $5 \mathrm{~h}$ with $0.24 \mathrm{mg}$ of $\mathrm{His}_{6}$-TEV protease in $1 \mathrm{mmoll}^{-1} \mathrm{DTT}, 50 \mathrm{mmoll}^{-1}$ Tris, $\mathrm{pH}$ 8.0. The incubation products were then loaded onto a Ni-NTA agarose column. The cleaved eppin flowed through the column, while $\mathrm{His}_{6}-\mathrm{TEV}$-eppin and $\mathrm{His}_{6}$-TEV protease bound to the column. The cleaved eppin was collected and stored at $-70{ }^{\circ} \mathrm{C}$ until the immunogenicity study. All fractions obtained in the isolation process were analyzed by $15 \%$ SDS-PAGE followed by staining, scanning and protein band quantification as described above. Purity was expressed as cleaved eppin/ total protein in fraction $\times 100 \%$. 


\section{Western blot}

Protein samples were separated on 15\% SDS-PAGE gels and electrotransferred to polyvinyldifluoride membrane using a semidry electrophoretic transblotter (Bio-Rad, Hercules, CA, USA). The membrane was blocked with 5\% non-fat milk in Tris-buffered saline ( $\mathrm{pH} 7.4$ ) supplemented with $0.1 \%(\mathrm{v} / \mathrm{v})$ Tween-20 (TBST) for $2 \mathrm{~h}$ and then incubated at $4{ }^{\circ} \mathrm{C}$ overnight with rabbit eppin antibody $(1: 1000$; Santa Cruz Biotechnology, Santa Cruz, CA, USA) diluted in blocking solution. The membrane was washed three times in TBST and probed with peroxidase-conjugated goat anti-rabbit IgG (1:5000; Beijing ZhongShan Biotechnology Co., Beijing, China) for $1 \mathrm{~h}$ at $37^{\circ} \mathrm{C}$. After washing, specific signals were detected using enhanced chemiluminescence Western blotting detection reagents (Amersham Life Science Ltd, Little Chalfont, UK).

\section{Protein determination}

Protein concentration was measured as described by Bradford ${ }^{20}$ with bovine serum albumin as a standard.

\section{Immunogenicity study of eppin}

Purified recombinant eppin was used in the immunogenicity study. Twenty specific pathogen-free Balb/c male mice (6-8 weeks old) were obtained from Shanghai Laboratory Animal Research Center (Shanghai, China) and randomly divided into three groups (phosphate-buffered saline (PBS) group, eppin group and eppin-alone group). The mice were maintained with food and water ad libitum in a temperature-controlled room with a 12-h light/12-h dark cycle. Mice of the eppin group were immunized by subcutaneous injection on the hindlimb of $100 \mu \mathrm{g}$ of eppin diluted in $100 \mu \mathrm{l}$ of PBS, $\mathrm{pH} 7.2$, and emulsified with an equal volume of complete Freund's adjuvant for the primary immunisation (day 1). Freund's incomplete adjuvant was used in the boost immunisation on day 17. Animals of the PBS group and the eppin-alone group received the same injections as the eppin group but without eppin or adjuvant, respectively. Serum samples were taken from mice of all groups on days $0,15,31,45$ (weeks $0,2,4$ and 6 after the first immunisation) and assayed for anti-eppin IgG.

Antibody titers were determined by enzyme-linked immunosorbent assay in 96-well microplates. The plates were coated with $100 \mu \mathrm{l}$ per well of purified recombinant eppin at a concentration of $0.001 \mathrm{mg} \mathrm{ml}^{-1}$ in coating buffer $\left(50 \mathrm{mmol} \mathrm{l}^{-1}\right.$ sodium bicarbonate, $\mathrm{pH}$ 9.6) at $4{ }^{\circ} \mathrm{C}$ in a humidified atmosphere overnight. The plates were washed three times with TBST, and $200 \mu$ of blocking buffer (5\% non-fat milk in TBST, pH 7.6) was added to each well. The plates were incubated at $37{ }^{\circ} \mathrm{C}$ for $2 \mathrm{~h}$ and washed three times with TBST. After washing, $100 \mu \mathrm{l}$ of appropriately diluted mouse serum was added to the wells of the blocked plates. The plates were incubated for $2 \mathrm{~h}$ at $37{ }^{\circ} \mathrm{C}$ and washed as previously described. Horseradish peroxidase-conjugated goat anti-mouse IgG was diluted to $1: 5000$ with $5 \%$ non-fat milk in TBST, added (100 $\mu$ l per well) to each well and incubated at $37{ }^{\circ} \mathrm{C}$ for $1 \mathrm{~h}$. The plates were washed three times with TBST. One hundred microliters of TMB substrate (Tiangen, Beijing, China) were then added to each well, and the plates were incubated in the dark at $37^{\circ} \mathrm{C}$ for $15 \mathrm{~min}$. The reaction was stopped with $50 \mu \mathrm{l}$ per well of $2 \mathrm{mmol} \mathrm{l}^{-1} \mathrm{H}_{2} \mathrm{SO}_{4}$ solution, and the absorbance was measured at $450 \mathrm{~nm}$ (Bio-tek, Winooski, VT, USA). The end-point titer of the individual plasma samples was considered positive if the absorbance was at least twofold higher than the background. The mean \pm s.e.m. of antibody titers was calculated for each group at each serum collection.

\section{RESULTS}

Construction of expression plasmid pET28a (+)-His ${ }_{6}$-eppin

The coding sequence of eppin lacking part of the $N$-terminal secretory sequence was cloned into the T7 promoter-driven fusion expression vector pET28a $(+)$ (Figure 1). The resulting plasmid, pET28a $(+)-$ His $_{6}$-eppin, was analyzed by polymerase chain reaction and restriction enzyme digestion and confirmed by DNA sequencing (data not shown).

\section{Expression of $\mathrm{His}_{6}$-TEV-eppin in E. coli}

The prokaryotic expression vector pET28a $(+)-\mathrm{His}_{6}$-eppin was transformed into the E. coli BL21 Star (DE3) expression host strain for protein expression. A small-scale time course experiment was performed to determine the optimal induction time for protein expression by the bacterial culture. The largest amount of correctly sized $(17 \mathrm{kDa}) \mathrm{His}_{6}$-TEV-eppin protein was present $4 \mathrm{~h}$ after IPTG induction; therefore, the cells were harvested at this time point (Figure 2a and $\mathbf{b}$ ). The expressed protein was present predominantly in the insoluble fraction as inclusion bodies (Figure 2c). Inclusion bodies are useful because their formation generally leads to high protein expression levels and because they protect the protein from protease activity within the cell. ${ }^{21}$ The presence of proteins in inclusion bodies also limits the number of purification steps needed because few contaminants are present within the inclusion bodies. ${ }^{22}$ The results presented here show that recombinant $\mathrm{His}_{6}$-TEV-eppin can be highly expressed in the inclusion bodies of the host cells.

\section{Purification of $\mathrm{His}_{6}$-TEV-eppin from inclusion bodies}

For large-scale protein expression, about $30 \mathrm{mg}$ of $\mathrm{His}_{6}$-TEV-eppin was obtained from 11 of culture (Figure 2d). For successful renaturation of the protein, it was necessary to completely remove the urea and imidazole from the protein solution. To improve the solubility of the His $_{6}$-TEV-eppin during dilution and refolding, we added the redox components GSH and GSSG and $0.4 \mathrm{~mol}^{-1} \mathrm{~L}$-arginine to the refolding buffer. Ultrafiltration was subsequently performed to remove the urea and imidazole and to concentrate the refolded protein. A refolding efficiency of approximately $40 \%$ was achieved with this method,

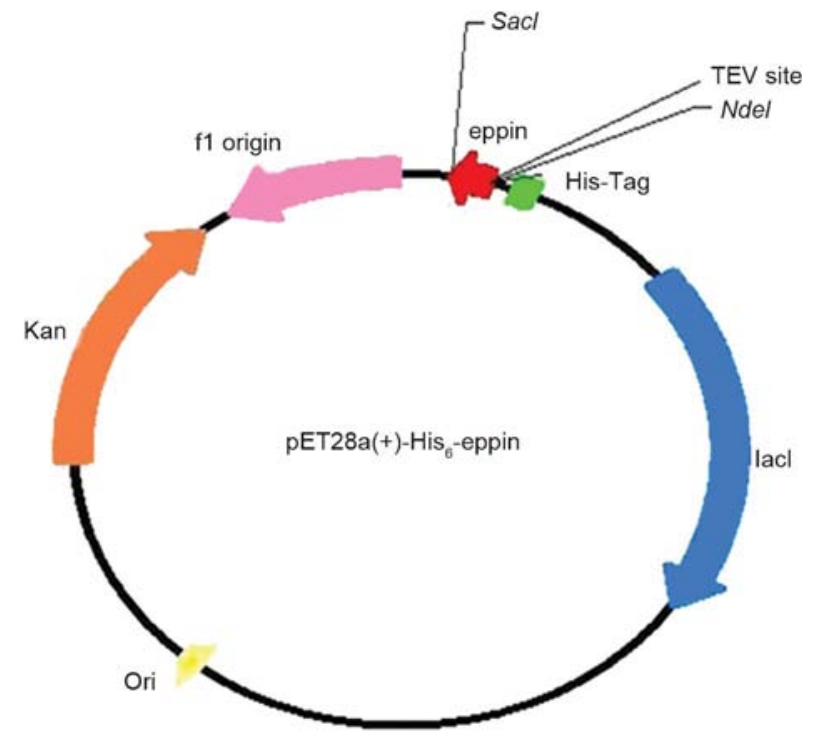

Figure 1 Diagram of the recombinant expression plasmid pET28a $(+)-\mathrm{His}_{6}{ }^{-}$ eppin. eppin, epididymal protease inhibitor; TEV, tobacco etch virus. 


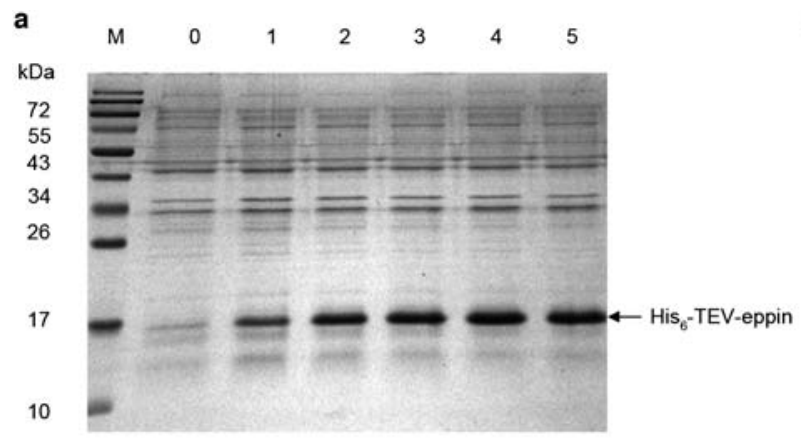

C

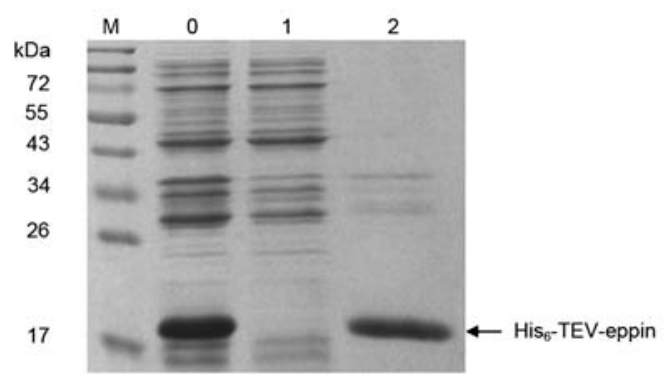

b

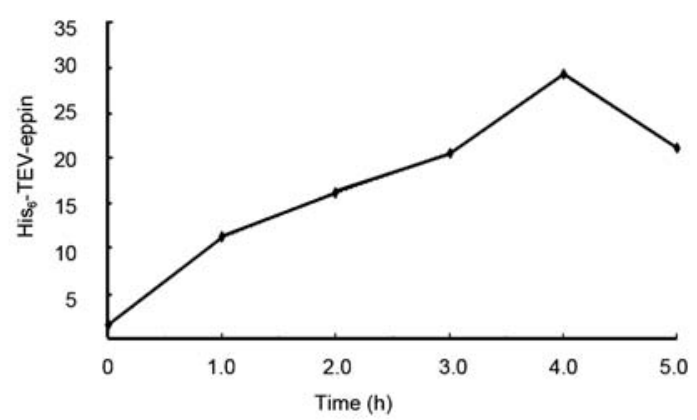

d

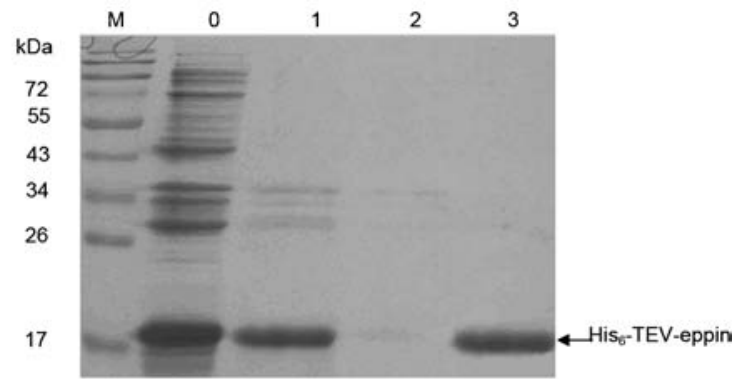

Figure 2 Analysis of the expression and purification of $\mathrm{His}_{6}$-TEV-eppin. (a) SDS-PAGE analysis of $\mathrm{His}_{6}$-TEV-eppin induced with 1 mmol I-1 of IPTG at different times (representative of three independent experiments). M, protein marker; 0, untreated; 1-5, treated for 1-5 h. (b) Quantitative analysis of SDS-PAGE (representative of three independent experiments). The time course of IPTG induction of His 6 -TEV-eppin expression, as determined by quantitative analysis of the gel after SDS-PAGE, is plotted. (c) SDS-PAGE analysis of the localisation of His ${ }_{6}$-TEV-eppin induced by IPTG (representative of three independent experiments). M, protein marker; 0, total cellular proteins from induced cells harboring His $\sigma_{-}$TEV-eppin; 1 , cellular supernatant fraction; 2 , cellular insoluble fractions. (d) SDS-PAGE analysis of the purification of the recombinant protein His ${ }_{6}$-TEV-eppin (representative of three independent experiments). M, protein marker; 0 , total cellular proteins from induced cells harboring pET28a (+)-eppin; 1, inclusion bodies dissolved in $8 \mathrm{~mol} \mathrm{I}^{-1}$ urea; 2, wash fractions from affinity chromatography; 3, eluted fraction from affinity chromatography. eppin, epididymal protease inhibitor; SDS, sodium dodecyl sulfate; TEV, tobacco etch virus.

yielding approximately $12 \mathrm{mg}$ of refolded $\mathrm{His}_{6}$-TEV-eppin from 11 of culture.

\section{Cleavage of the $\mathrm{His}_{6}$-tag and purification of eppin}

After the recombinant fusion protein had been successfully purified, renatured, filtered and concentrated, the next step was to remove the
$\mathrm{His}_{6}$-tag. As shown in Figure 3a, the optimal time for the cleavage of the $\mathrm{His}_{6}$-tag of $\mathrm{His}_{6}$-TEV-eppin by TEV was $5 \mathrm{~h}$. Following TEV treatment, the digested sample was again loaded onto the Ni-NTA agarose column. The nickel beads bound the cleaved $\mathrm{His}_{6}$-tag fragment and the TEV endoprotease, whereas the eppin did not bind to the column (Figure $3 \mathbf{b}$ ). Approximately $2 \mathrm{mg}$ of eppin was obtained from
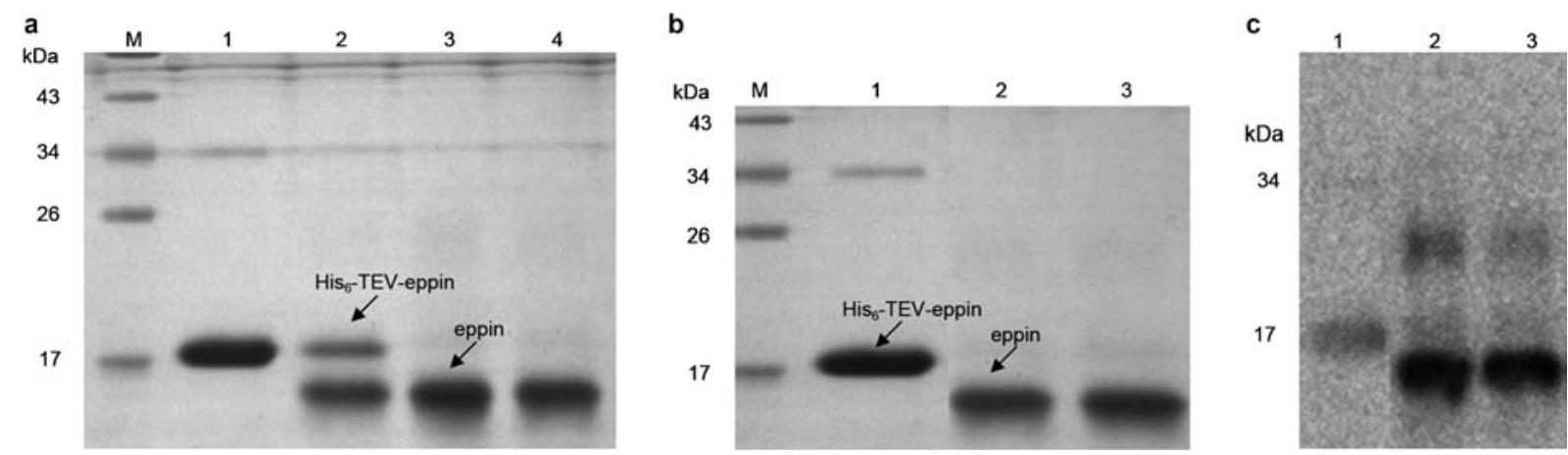

Figure 3 Analysis of $\mathrm{His}_{6}$-TEV-eppin digested by His ${ }_{6}$-TEV protease. (a) SDS-PAGE and time course of His ${ }_{6}$-TEV-eppin digested by His ${ }_{6}$-TEV protease (representative of three independent experiments). His $\sigma_{-}$TEV-eppin $\left(0.5 \mathrm{mg}\right.$ ) was incubated with $0.01 \mathrm{mg} \mathrm{His}{ }_{-}-\mathrm{TEV}$ protease (TEV/substrate ratio $=1: 50$ ) at $20{ }^{\circ} \mathrm{C}$ for different times (lanes 1-4: 0, 2.5, 5 and $7 \mathrm{~h}$, respectively) in $1 \mathrm{mmol} \mathrm{I}^{-1}$ DTT, $50 \mathrm{mmol} \mathrm{I}^{-1}$ Tris, pH 8.0. All samples were analyzed by 15\% SDS-PAGE. Cleavage of the $17 \mathrm{kDa}$ His ${ }^{-}$ TEV-eppin produced a 14-kDa eppin product. (b) SDS-PAGE analysis of His ${ }_{6}$-TEV-eppin digested by His ${ }_{6}-\mathrm{TEV}_{\text {- }}$ protease (representative of three independent experiments). $\mathrm{His}_{6}-\mathrm{TEV}$-eppin (12 mg) was incubated with $0.24 \mathrm{mg}$ of $\mathrm{His}_{6}-\mathrm{TEV}$ protease (TEV/substrate ratio $=1: 50$ ) at $20^{\circ} \mathrm{C}$ for $5 \mathrm{~h}$ in $1 \mathrm{mmol} \mathrm{I}^{-1} \mathrm{DTT}, 50 \mathrm{mmol} \mathrm{I}^{-1}$ Tris, pH 8.0. All samples were analyzed by 15\% SDS-PAGE. Cleavage of the 17-kDa His 6 -TEV-eppin produced a 14-kDa eppin product. Lane M: protein marker; lane

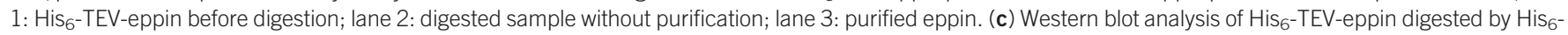
TEV protease. Lane 1: His 6 -TEV-eppin protein before digestion; lane 2: digested sample without purification; lane 3: purified eppin. Molecular weight markers (kDa) are indicated to the left of the blots. eppin, epididymal protease inhibitor; SDS, sodium dodecyl sulfate; TEV, tobacco etch virus. 
the starting amount of $12 \mathrm{mg}$ of $\mathrm{His}_{6}$-TEV-eppin using this process. As analyzed by SDS-PAGE followed by Coomassie blue staining, the purity of the eppin was about $95 \%$.

Western blotting of recombinant eppin demonstrated that a $17-\mathrm{kDa}$ monomer and a $34-\mathrm{kDa}$ dimer were present before cleavage; a predominant immunoreactive band of $\sim 14 \mathrm{kDa}$ and minor bands of $\sim 28 \mathrm{kDa}$ were detected after the fusion protein was cleaved (Figure 3c).

\section{Immunogenicity study of eppin}

Serum samples from the vaccinated mice were titered for IgG specific to purified eppin by serial dilution with a standard enzyme-linked immunosorbent assay. Serum from the group of mice injected only with PBS was used to determine the background level of the immunoassay. The mean reciprocal of end-point titers for each group of animals at different times is shown in Figure 4. Two weeks later after the initial immunisation, an antigen-specific IgG antibody response was detected in the eppin protein group; however, the mean reciprocal end-point dilution titer did not exceed 1000 until after the boost immunisation (Figure 4). By day 31 (4 weeks), animals in the eppin group showed a strong antibody response; the mean reciprocal endpoint dilution titer \pm s.e.m. was $13733 \pm 2554$, and the high titer IgG was maintained for at least 2 weeks (the end-point dilution titer was 16 $267 \pm 1392$ at day 45 (6 weeks)). These results indicate that purified eppin can stimulate powerful humoral immunity.

\section{DISCUSSION}

Although affinity tags provide highly efficient tools for protein purification, the presence of an affinity tag in a recombinant protein may be unnecessary or represent a disadvantage for the clinical use of the protein. ${ }^{23}$ In this study, we present a method for producing tag-free eppin.

We constructed the pET28a (+)-His - $_{6}$-eppin plasmid with an intervening TEV endoprotease recognition site, followed by transformation into the E. coli BL21 Star (DE3) expression host strain for protein expression. Because most of the recombinant $\mathrm{His}_{6}-\mathrm{TEV}$-eppin produced in E. coli formed inclusion bodies, we purified the fusion protein under denaturing conditions.

To cleave the $\mathrm{His}_{6}$-tag with TEV protease, it was necessary to remove the urea and imidazole and refold the proteins. The use of additives during the refolding process often helps to improve the yield

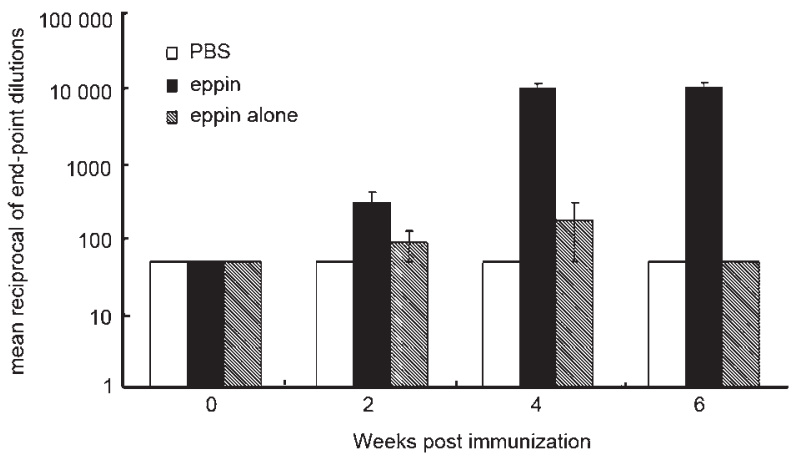

Figure 4 Specific immune response in Balb/c mice injected with eppin. The eppin group received eppin mixed with complete Freund's adjuvant, and Freund's incomplete adjuvant was used in the booster. As controls, the eppinalone group received eppin without adjuvant, while the PBS group received two injections containing only adjuvant and PBS. eppin, epididymal protease inhibitor; PBS, phosphate-buffered saline. of biologically active protein from inclusion bodies. ${ }^{24} \mathrm{~L}$-Arginine is known to reduce the aggregation of a number of proteins. ${ }^{25-27}$ In addition, eppin has 14 cysteine residues (10.5\% cysteine content), and the correct refolding of this protein requires that a redox system be present in the refolding solution. Therefore, during the dilution refolding procedure, $L$-arginine and GSH/GSSG were added to improve the solubility of $\mathrm{His}_{6}$-TEV-eppin. A refolding efficiency of about $40 \%$ was achieved. After cleavage and separation on a Ni-NTA agarose column, $2 \mathrm{mg}$ of eppin without the $\mathrm{His}_{6}$-tag was isolated from 11 of culture with a purity of $>95 \%$.

The purified eppin exhibited excellent immunogenicity. After immunisation of male Balb/c mice with purified eppin mixed with Freund's adjuvant, the highest end-point dilution titer in serum was above 10000 , and the high titer of IgG could be maintained for at least 2 weeks.

This paper describes a novel method for the production of recombinant human eppin without a $\mathrm{His}_{6}$-tag. The method described in this work should facilitate further studies of the structure and function of eppin and may also permit the large-scale production of biologically active recombinant human eppin suitable for use in a contraceptive vaccine for men.

\section{AUTHOR CONTRIBUTIONS}

$\mathrm{JZ}$ and XLD designed and performed experiments, analyzed data and wrote the paper; ZHB performed experiments; YKX, SLW, LS and XRW supervised the project.

\section{COMPETING FINANCIAL INTERESTS}

The authors declare no competing financial interests.

\section{ACKNOWLEDGEMENTS}

The authors are grateful to Dr Zi-Chun Hua (The State Key Laboratory of Pharmaceutical Biotechnology and Department of Biochemistry, College of Life Science, Nanjing University, China) for kindly providing plasmid pET28a $(+)$ and TEV endoprotease and to Dr Michael G. O'Rand (Laboratories for Reproductive Biology and Department of Cell and Developmental Biology, University of North Carolina at Chapel Hill, USA) for English-language editing. This study was supported by grants from the Key Project of the National Natural Science Foundation of China (No. 30930079) and the Chinese National Nature Science Foundation (No. 81001257).

1 O'Rand MG, Widgren EE, Sivashanmugam P, Richardson RT, Hall SH et al. Reversible immunocontraception in male monkeys immunized with Eppin. Science 2004; 306 1189-90.

2 Richardson RT, Sivashanmugam P, Hall SH, Hamil KG, Moore PA et al. Cloning and sequencing of human Eppin: a novel family of protease inhibitors expressed in the epididymis and testis. Gene 2001; 270: 93-102.

3 Sivashanmugam P, Hall SH, Hamil KG, French FS, O'Rand MG et al. Characterization of mouse Eppin and a gene cluster of similar protease inhibitors on mouse chromosome 2. Gene 2003; 312: 125-34.

4 Zhang J, Ding X, Bian Z, Xia Y, Lu C et al. The effect of anti-eppin antibodies on ionophore A23187-induced calcium influx and acrosome reaction of human spermatozoa. Hum Reprod 2010; 25: 29-36.

5 O'Rand MG, Widgren EE, Beyler S, Richardson RT. Inhibition of human sperm motility by contraceptive anti-eppin antibodies from infertile male monkeys: effect on cyclic adenosine monophosphate. Biol Reprod 2009; 80: 279-85.

6 Wang Z, Widgren EE, Sivashanmugam P, O'Rand MG, Richardson RT. Association of eppin with semenogelin on human spermatozoa. Biol Reprod 2005; 72: 1064-70.

7 Yenugu S, Richardson RT, Sivashanmugam P, Wang Z, O'Rand MG et al. Antimicrobial activity of human EPPIN, an androgen-regulated, sperm-bound protein with a whey acidic protein motif. Biol Reprod 2004; 71: 1484-90.

8 Dubé E, Hermo L, Chan PT, Cyr DG. Alterations in gene expression in the caput epididymides of nonobstructive azoospermic men. Biol Reprod 2008; 78: 342-51.

9 Ding X, Zhang J, Fei J, Bian Z, Li Y et al. Variants of the EPPIN gene affect the risk of idiopathic male infertility in the Han-Chinese population. Hum Reprod 2010; 25: $1657-65$. 
10 Ding X, Zhang J, Bian Z, Xia Y, Lu C et al. Variants in the Eppin gene show association with semen quality in Han-Chinese population. Reprod Biomed Online 2010; 20: 125-31.

11 Liang S, Gong F, Zhao X, Wang X, Shen G et al. Prokaryotic expression, purification of a new tumor-relative protein FAM92A1-289 and its characterization in renal cell carcinoma. Cancer Lett 2009; 276: 81-7.

12 Zhu QY, Gu XJ, Yang J, Wang JH, Tang B et al. Purification and characterization of biologically active recombinant human Eppin expressed in Escherichia coli. Chin Med $J$ (Engl) 2008; 121: 620-4.

13 McCrudden MT, Dafforn TR, Houston DF, Turkington PT, Timson DJ. Functional domains of the human epididymal protease inhibitor, eppin. FEBS J 2008; 275: 1742-50.

14 Chant A, Kraemer-Pecore CM, Watkin R, Kneale GG. Attachment of a histidine tag to the minimal zinc finger protein of the Aspergillus nidulans gene regulatory protein AreA causes a conformational change at the DNA-binding site. Protein Expr Purif 2005; 39: 152-9.

15 Tropea JE, Cherry S, Waugh DS. Expression and purification of soluble $\mathrm{His}_{6}$-tagged TEV protease. Methods Mol Biol 2009; 498: 297-307.

16 Gaberc-Porekar V, Menart V. Perspectives of immobilized-metal affinity chromatography. J Biochem Biophys Methods 2001; 49: 335-60.

17 Nilsson J, Ståhl S, Lundeberg J, Uhlén M, Nygren PA. Affinity fusion strategies for detection, purification, and immobilization of recombinant proteins. Protein Expr Purif 1997; 11: 1-16.
18 Zheng N, Pérez Jde J, Zhang Z, Domínguez E, Garcia JA et al. Specific and efficient cleavage of fusion proteins by recombinant plum pox virus Nla protease. Protein Expr Purif 2008; 57: 153-62

19 Jenny RJ, Mann KG, Lundblad RL. A critical review of the methods for cleavage of fusion proteins with thrombin and factor Xa. Protein Expr Purif 2003; 31: 1-11.

20 Bradford MM. A rapid and sensitive method for the quantitation of microgram quantities of protein utilizing the principle of protein-dye binding. Anal Biochem 1976; 72: 248-54.

21 Singh SM, Panda AK. Solubilization and refolding of bacterial inclusion body proteins. J Biosci Bioeng 2005; 99: 303-10.

22 Rudolph R, Lilie H. In vitro folding of inclusion body proteins. FASEB J 1996; 10: 49-56.

23 Arnau J, Lauritzen C, Petersen GE, Pedersen J. Current strategies for the use of affinity tags and tag removal for the purification of recombinant proteins. Protein Expr Purif 2006; 48: 1-13.

24 Clark ED. Refolding of recombinant proteins. Curr Opin Biotechnol 1998; 9: 157-63.

25 Arakawa T, Tsumoto K. The effects of arginine on refolding of aggregated proteins: not facilitate refolding, but suppress aggregation. Biochem Biophys Res Commun 2003; 304: 148-52.

26 Arora $D$, Khanna N. Method for increasing the yield of properly folded recombinant human gamma interferon from inclusion bodies. J Biotechnol 1996; 52: 127-33.

27 Umetsu M, Tsumoto K, Hara M, Ashish K, Goda S et al. How additives influence the refolding of immunoglobulin-folded proteins in a stepwise dialysis system. Spectroscopic evidence for highly efficient refolding of a single-chain Fv fragment. J Biol Chem 2003; 278: 8979-87. 